\title{
Seasonal variations in plant nitrogen relations and photosynthesis along a grassland to shrubland gradient in Owens Valley, California
}

\author{
C. M. Goedhart • D. E. Pataki • S. A. Billings
}

Received: 30 January 2009 / Accepted: 25 May 2009 / Published online: 5 June 2009

(C) The Author(s) 2009. This article is published with open access at Springerlink.com

\begin{abstract}
Community composition in semi-arid ecosystems has largely been explained by water availability; however, nitrogen is a common limiting nutrient, and may be an important control on plant function and carbon uptake. We investigated nitrogen relations and photosynthesis of several dominant species at shallow groundwater sites in Owens Valley, California. We measured soil nitrogen $(\mathrm{N})$ availability, leaf $\mathrm{N}$ and isotopes, water isotopes, and gas exchange of dominant shrub species Atriplex torreyi and Ericameria nauseosa and grass species Distichlis spicata throughout the summer season in three sites that had similar watertable depths, but that varied in community composition and $\mathrm{N}$ availability. Surface soil inorganic $\mathrm{N}$ was greatest at the grassland site and
\end{abstract}

Responsible Editor: Tibor Kalapos.

C. M. Goedhart $(\bowtie) \cdot$ D. E. Pataki

Department of Ecology \& Evolutionary Biology,

University of California, Irvine,

Irvine, CA 92697, USA

e-mail: cgoedhar@uci.edu

\section{E. Pataki}

Department of Earth System Science, University of California, Irvine,

Irvine, CA 92697, USA

\section{S. A. Billings}

Department of Ecology and Evolutionary Biology,

Kansas Biological Survey, University of Kansas,

Lawrence, KS 66047, USA declined from June to September at all sites. Leaf N declined throughout the season in all species, and was correlated with soil inorganic N. Photosynthesis of $A$. torreyi remained relatively constant throughout the season. In contrast, D. spicata and E. nauseosa experienced seasonal declines in photosynthesis at sites with greater inorganic $\mathrm{N}$ availability. Leaf $\mathrm{N}$ was significantly correlated with photosynthesis in $D$. spicata across all sites and measurement periods. Controls on $\mathrm{N}$ cycling are likely to be an important determinant of photosynthesis of D. spicata in this region.

Keywords Atriplex torreyi Distichlis spicata . Ericameria nauseosa . Great Basin Desert .

Nitrogen relations $\cdot$ Photosynthesis

\section{Introduction}

Owens Valley, California has been an important source of water for the city of Los Angeles for nearly one hundred years. Located in the rainshadow of the Sierra Nevada in the Great Basin Desert, the valley receives only $130 \mathrm{~mm}$ of precipitation on average per year, approximately $80 \%$ of which falls during winter months (Inyo County Water Department 2006). However, spring and summer snow melt from the adjacent mountain ranges annually recharges groundwater throughout the valley, resulting in relatively shallow watertable 
depths. Subsequently, many plant communities contain phreatophytic, groundwater dependent species. Recent studies have suggested that lowering of the water table caused by groundwater pumping and diversion of water to Los Angeles has led to decreases in live plant cover, primarily in groundwater dependent grasses and phreatophytic shrubs (Elmore et al. 2003, 2006; Griepentrog and Groeneveld 1981).

Most studies of species distribution in the region have focused almost exclusively on the role of water availability in influencing the abundance of shrubs versus grasses (Elmore et al. 2003, 2006; Griepentrog and Groeneveld 1981; Groeneveld and Or 1994; Groeneveld et al. 1994; Naumburg et al. 2005; Sorenson et al. 1991). However, within a given watertable depth, community composition can be extremely variable, suggesting that other factors such as soil nutrients may play a critical role in plant function and distribution. In particular, nitrogen $(\mathrm{N})$ is a highly limiting resource in arid ecosystems (Hadley and Szarek 1981) that is also an important determinant of ecosystem processes (Drenovsky and Richards 2006; James and Richards 2007; James et al. 2005; McLendon and Redente 1992; Pataki et al. 2005). In semi-arid ecosystems, $\mathrm{N}$ mineralization is greatly limited by shallow soil moisture and occurs in pulses following rain events (Bilbrough and Caldwell 1997; Cui and Caldwell 1997). While groundwater is abundant in Owens Valley, there is little summer growing season precipitation. Therefore, there is a large decline in soil moisture in the upper soil layers during the growing season (Carbone et al. 2008; Steinwand et al. 2006) that likely limits $\mathrm{N}$ mineralization.

Although $\mathrm{N}$ availability in semi-arid ecosystems is pulse-driven, the ability to take up $\mathrm{N}$ following precipitation events varies greatly among species in these systems (Bilbrough and Caldwell 1997; Gebauer and Ehleringer 2000; James and Richards 2006; James et al. 2006; Snyder et al. 2004). In a study involving Great Basin shrub species, the deep rooted Ericameria nauseosa (formerly Chrysothamnus nauseosus) was the only species to have an increased growth response to a summer precipitation event (Snyder et al. 2004). Studies within Owens Valley have documented interannual variability in plant productivity and cover coinciding with interannual variability in precipitation patterns, even when plants have adequate access to groundwater (Groeneveld et al. 1994; Sorenson et al. 1991). While these results have not been explicitly linked to $\mathrm{N}$ availability, they suggest that there may be an ecologically important relationship between shallow soil water, soil $\mathrm{N}$ availability, and plant growth.

Soils in Owens Valley tend to be saline and both halophytic and glycophytic species are common. We have shown previously that grasses in the central Owens Valley near Bishop, CA utilize shallow, isotopically enriched sources of water, unlike neighboring shrubs which appear to rely on groundwater when water tables are within $3 \mathrm{~m}$ of the surface (Pataki et al. 2008). In that study, grasses exhibited similar leaf $\mathrm{N}$ concentrations and isotopic composition as glycophytic shrubs, but halophytic shrubs showed higher concentrations of leaf N. In particular, the halophytic shrub Atriplex torreyi showed high concentrations of leaf $\mathrm{N}$ that were isotopically enriched relative to other species. Isotopically enriched leaf $\mathrm{N}$ corresponded to isotopically enriched soil $\mathrm{N}$ in the shallow surface soil associated with high rates of gaseous $\mathrm{N}$ losses (Pataki et al. 2008). Atriplex torreyi appears to have a competitive advantage in $\mathrm{N}$ uptake in the saline upper soil layers - where $\mathrm{N}$ availability is generally higher than deeper in the soil profile - that may influence its patterns of growth and distribution. However, seasonality in $\mathrm{N}$ uptake and its relationship to carbon uptake was not evaluated in that study.

In this study, we measured temporal changes in plant and soil water and $\mathrm{N}$ relations during the growing season to compare species and evaluate the effects of changing resource availability on photosynthesis. We hypothesized that as soil moisture declines during the growing season, soil inorganic $\mathrm{N}$ availability will decline, with different consequences for $\mathrm{N}$ uptake and photosynthesis among grass and shrub species. We expected that the halophytic shrub Atriplex torreyi would have relatively constant leaf $\mathrm{N}$ throughout the season, since this species appears to have a competitive advantage in $\mathrm{N}$ uptake in saline soils. In contrast, we expected that leaf $\mathrm{N}$ in the halophytic grass, Distichlis spicata, and glycophytic shrub species, Ericameria nauseosa, would decline over the season. Consequently, we hypothesized that leaf $\mathrm{N}$ and carbon uptake would remain constant throughout the season for Atriplex torreyi, but would decrease for Distichlis spicata and Ericameria nauseosa. An overall goal of this study is to add an understanding of plant $\mathrm{N}$ relations to the growing understanding of the role of water availability in influencing plant 
distributions and community structure in this hydrologically and ecologically important region.

\section{Materials and methods}

Study sites

Three sites with similar depth to watertable (DTW) near Bishop, California were chosen along a grassland to shrubland gradient. Detailed site descriptions are given in Pataki et al. (2008). Briefly, the grassland site had an average DTW of 1.5-2 m throughout the 2006 sampling period, and was composed predominantly of grass species, including Distichlis spicata, Sporobolus airoides, and Leymus triticoides. The intermediate site had an average DTW of 1.5-2 m throughout the 2006 sampling period, and was composed of both grass and shrub species. The shrubland site had an average DTW of 1.8-2 m throughout the 2006 sampling period, and was dominated by shrubs with very low grass cover. The dominant species for both the intermediate and shrubland sites were the shrubs Atriplex torreyi, Ericameria nauseosa, Sarcobatus vermiculatus, and the grasses Distichlis spicata and Sporobolus airoides. We chose these sites to control for groundwater depth while varying the relative abundance of shrubs and grasses.

Measurements in this study focused on Atriplex torreyi (S. Wats.), Ericameria nauseosa (Pall. ex Pursh), and Distichlis spicata (L.) Greene. A. torreyi is a $\mathrm{C}_{4}$, winter deciduous, halophytic shrub known to be a successful competitor in both water stressed and non-water stressed environments (Naumburg et al. 2005). E. nauseosa, formerly known as Chrysothamnus nauseosus, is a winter deciduous, $\mathrm{C}_{3}$ phreatophytic shrub that depends predominantly on groundwater (Donovan and Ehleringer 1994; Leffler et al. 2004). When the watertable drops below the rooting zone, $E$. nauseosa is susceptible to significant dieback and mortality (Toft 1995). Finally, D. spicata is a $C_{4}$ perennial halophytic grass commonly found in salt marshes and areas with relatively shallow watertables (Dahlgren et al. 1997; Elmore et al. 2006).

Soil inorganic $\mathrm{N}$ measurements

In June and September 2006, soil samples were collected at each site by combining a composite of three subsamples from $0-15 \mathrm{~cm}$ depth underneath 3 individuals of each shrub species and in 3 grass dominated intershrub spaces. Soil samples were immediately chilled at $4^{\circ} \mathrm{C}$ until extracted with $2 \mathrm{M}$ $\mathrm{KCl}$ and analyzed for ammonium and nitrate colorimetrically. In addition, in situ soil inorganic $\mathrm{N}$ availability was determined in August using 3-5 $2.5 \times 5 \mathrm{~cm}$ cation and anion resin strips under 3 individuals of each shrub species and in 3-5 relatively open areas (GE Infrastructure Water \& Process Technologies, Watertown, MA), placed in the top $5 \mathrm{~cm}$ of the soil profile for 5 days. Resin strips were extracted with $2 \mathrm{M} \mathrm{KCl}$ and analyzed colorimetrically for ammonium and nitrate concentration.

Leaf isotope and nitrogen measurements

In June 2005 and in three intervals from June to mid September 2006, fully expanded sun leaves in the upper canopy from 3-5 individuals of each species, including the co-occurring halophytic shrub Sarcobatus vermiculatus, were collected and dried at approximately $65^{\circ} \mathrm{C}$ for at least $48 \mathrm{~h}$. Dried leaves were ground to a fine homogenous powder and analyzed for leaf carbon (C), nitrogen (N), and nitrogen stable isotope composition $\left(\delta^{15} \mathrm{~N}\right)$ using an elemental analyzer coupled to an Isotope Ratio Mass Spectrometer (Delta Plus IRMS, Thermofinnigan, San Jose, CA) at the University of California, Irvine. Nitrogen isotope ratios were expressed in common $\delta$ notation and referenced to the atmospheric standard with a precision of $0.16 \%$.

Plant/soil water isotopic measurements

In three intervals from June to mid September 2006, 3-5 non-green shrub stems and grass rhizomes from each species from each site were collected, stored in vacutainers sealed with parafilm, and immediately chilled in coolers in the field until frozen in the lab. Samples remained frozen until water was extracted with cryogenic vacuum distillation (West et al. 2006). Extracted water was frozen until analyzed for oxygen isotopic ratio $\left(\delta^{18} \mathrm{O}\right)$ using a thermal conversion elemental analyzer (TC EA, Thermofinnigan, San Jose, CA) coupled to an Isotope Ratio Mass Spectrometer (Delta Plus XP, Thermofinnigan, San Jose, CA) after Gehre et al. (2004). Similarly, soil samples were collected in three intervals from mid 
June to mid September 2006. Augers were used to extract soil from 3 cores at $\sim 10-20 \mathrm{~cm}$ depth intervals from 5-200 $\mathrm{cm}$ below the soil surface. Groundwater samples were collected from 11 wells located throughout the Owens Valley from Bishop to Independence. Samples were collected in vacutainers, frozen until water extraction, and analyzed for $\delta^{18} \mathrm{O}$. Oxygen isotope measurements were expressed in common $\delta$ notation and referenced to $\mathrm{V}-\mathrm{SMOW}$ within a precision of $0.19 \%$.

\section{Physiological measurements}

Photosynthesis was measured on 3-5 individuals of A. torreyi, E. nauseosa, and D. spicata at the three sites in June and August of 2005, and in six week intervals throughout the summer growing season from mid June to mid September in 2006. Measurements were made between the hours of 10:30 and 14:30 with a portable gas exchange system (LI6400, Licor, Inc, Lincoln, NE) at saturating light conditions (1500 $\mu \mathrm{mol} \cdot \mathrm{m}^{-2} \mathrm{~s}^{-1}$ photosynthetically actively radiation), vapor pressure deficit of $3.5-5 \mathrm{kPa}$, and ambient temperature (generally $\sim 37^{\circ} \mathrm{C}$ ). After each measurement, the measured shoot or leaf blades were harvested and the area of fresh leaves was measured (ImageJ software, NIH, Bethesda, MD) to express photosynthesis on a leaf area basis. Predawn water potential was measured on 3-8 individuals at each site during the same intervals in 2006 with a Scholandertype pressure chamber (Soil Moisture Equipment Corp., Santa Barbara, CA).

\section{Data analysis}

All data were analyzed using SAS 9.1.3 software (SAS Institute Inc., Cary, NC). Comparisons of measurements among sites and months were analyzed using the general linear model for Analysis of Variance or the t-test procedure, based on number of groupings. Post-hoc tests were conducted using the Tukey Standardized Range Test, and homogeneity of variance was tested using Levene's Test. Relationships between measurements were analyzed using simple and multiple regressions. Differences among slopes were tested using the ANCOVA procedure. Relationships with $p<0.05$ were considered significant, and $p<0.1$ were considered marginally significant.

\section{Results}

A trend of decreasing soil $\mathrm{KCl}$ extractable inorganic $\mathrm{N}$ from June to September 2006 was evident under all species at all sites, with significant declines in inorganic $\mathrm{N}$ under $D$. spicata in the grassland and shrubland sites, and under E. nauseosa in the intermediate site (Fig. 1a, $p<0.05$ ). Inorganic $\mathrm{N}$ concentrations were generally greater in soils from grassland and intermediate sites than the shrubland site $(p<0.0001)$. In addition, the percentage of inorganic soil $\mathrm{N}$ in the form of ammonium was greatest in the grassland and lowest in the intermediate site (Fig. 1a, $p<0.0001$ ). Percent ammonium did not change during the season under any species or at any site with the exception of $A$. torreyi in the shrubland, where percent ammonium increased during the season $(p<0.05)$. There were no overall species differences in either ammonium or nitrate availability as measured with resin strips $(p>0.1)$. Nitrate availability did not vary by site $(p<0.05)$, but ammonium availability was greater under $D$. spicata in the shrubland versus the intermediate site $(p<0.05)$.

Declines in soil inorganic $\mathrm{N}$ from June to September were consistent with an overall decrease in leaf percent $\mathrm{N}$ over the 2006 season for all species and sites except A. torreyi in the intermediate site and D. spicata in the shrubland site (Fig. 1b, $p<0.05$ ). Differences in leaf percent $\mathrm{N}$ among sites were apparent in June for both $D$. spicata and E. nauseosa. Leaf $\mathrm{N}$ in D. spicata was greater in both the grassland and intermediate sites than in the shrubland site (Fig. 1b, $p<0.001$ ). Likewise, percent leaf $\mathrm{N}$ in $E$. nauseosa was greater in the intermediate site than the shrubland site (Fig. 1b, $p<0.05$ ). Leaf $\mathrm{N}$ of all species, including the halophytic shrub Sarcobatus vermiculatus, was correlated with leaf $\delta^{15} \mathrm{~N}$ during each sampling period; this relationship was strongest when leaf $\mathrm{N}$ was expressed as $\mathrm{C}: \mathrm{N}$ ratio rather than leaf percent $\mathrm{N}$ (Fig. 2, $p<0.05$ ). The slope of this relationship was greater in September than in June (ANCOVA, $p<$ 0.05 ), with the non-halophytic shrub species and the halophytic grass species showing larger declines in leaf $\mathrm{N}$ late in the growing season than the two halophytic shrub species (Fig. 2).

We utilized the isotopic composition of stem water, soil water, and groundwater to evaluate the seasonality of plant access to shallow and deep soil water. Groundwater oxygen isotopes ranged from 

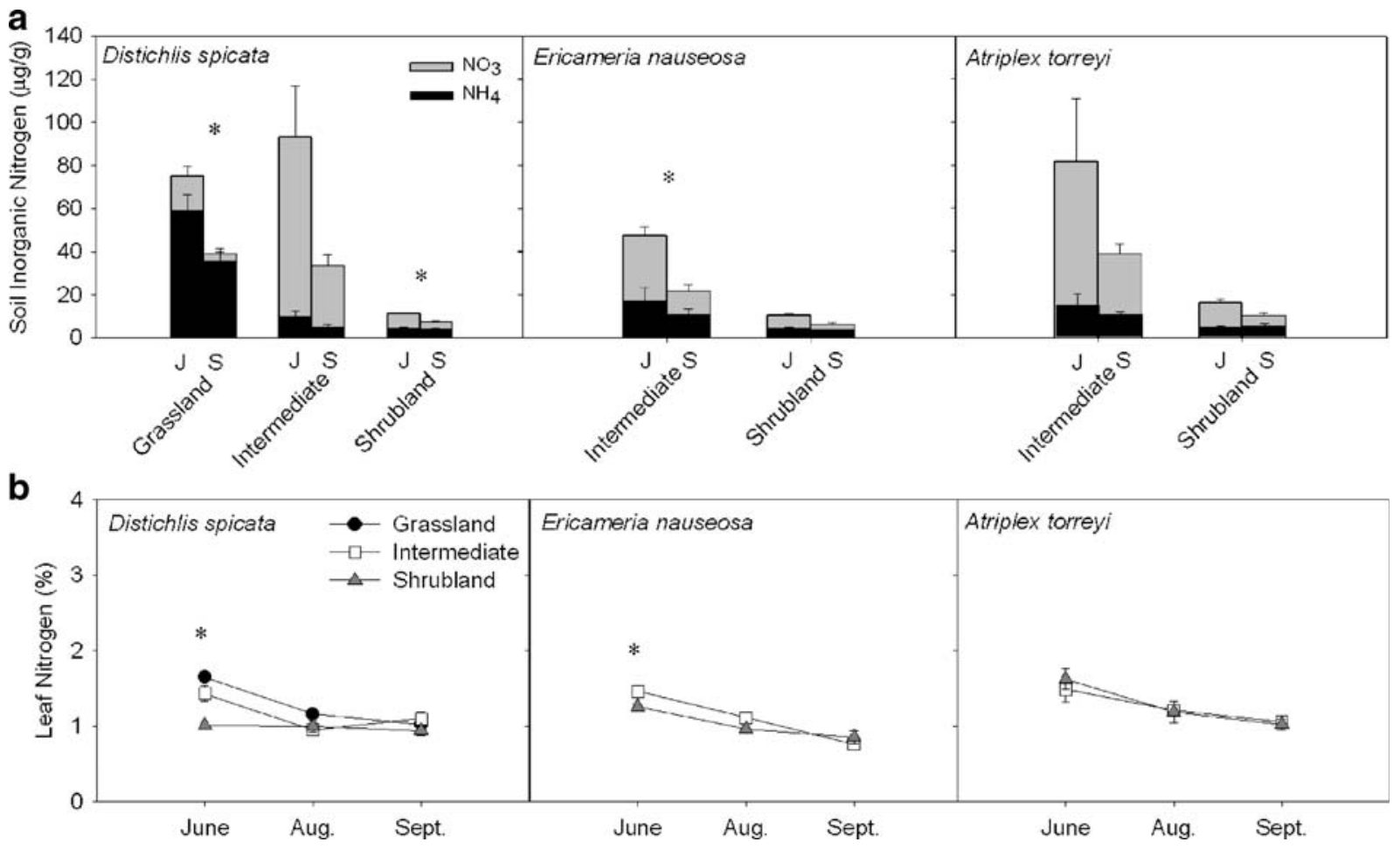

Fig. 1 a) Soil inorganic $\mathrm{N}$ in the form of nitrate and ammonium under each species at each site in July $(\mathrm{J})$ and September (S) 2006. b) Leaf percent $\mathrm{N}$ in each species and site

-15.0 to $-17.0 \%$, or $-16.2 \%$ on average (Fig. 3). The isotopic composition of soil water was similar to groundwater at depths exceeding approximately 35 , 65 , and $200 \mathrm{~cm}$ in the grassland, intermediate, and shrubland sites, respectively, with large enrichments at the soil surface (Fig. 3). The isotopic composition of soil water at all depths did not change throughout the season in the grassland site. Deeper soil water from $50-200 \mathrm{~cm}$ in the intermediate site was more isotopically enriched midway through the season than early in the season, and soil water at $50-100 \mathrm{~cm}$ in the shrubland site was more isotopically enriched early in the season than late in the season (Fig. 3, $p<0.05$ ). $D$. spicata rhizome water in the shrubland site was more enriched in August after a rain event in late July. E. nauseosa stem water became increasingly enriched over the season in the intermediate site (Fig. 4, $p<$ 0.05 ), and the isotopic composition of $A$. torreyi stem water did not vary significantly with time in either site (Fig. 4, $p>0.1$ ).

Overall, Atriplex torreyi showed the most negative predawn water potentials, particularly at the intermediate site (Fig. 5, $p<0.05)$. For all other species and in 2006. Error bars show one standard error (n varies from 3 to 5 replicates). Asterisks show significant differences among sites at $\alpha=0.05$

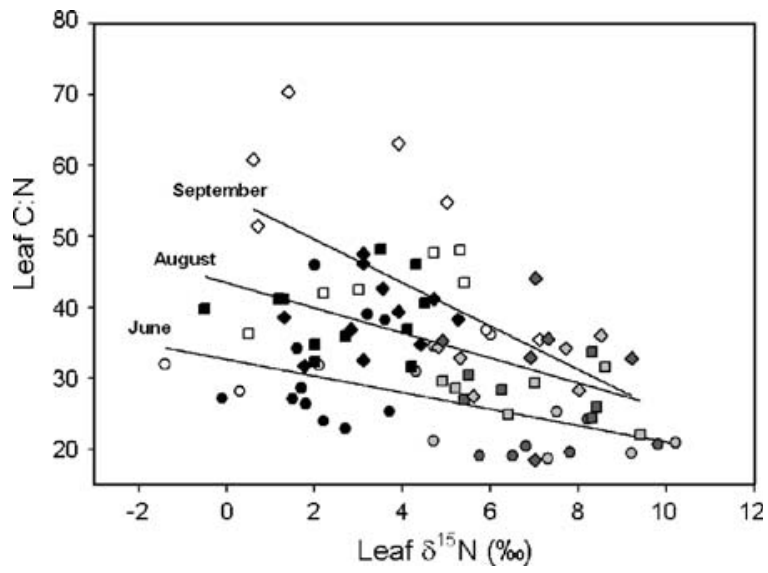

Fig. 2 Leaf $C: N$ versus leaf nitrogen isotope ratio $\left(\delta^{15} N\right)$ for dominant glycophytic shrub (Ericameria nauseosa - white symbols), halophytic grass (Distichlis spicata - black symbols) and halophytic shrub (Atriplex torreyi (light gray symbols), and Sarcobatus vermiculatus (dark gray symbols)) species in all sites in 2006 (June (circles), $\mathrm{r}^{2}=0.24, p<0.01$; August (squares), $\mathrm{r}^{2}=0.30, p<0.01$; September (diamonds), $\mathrm{r}^{2}=0.31$, $p<0.01)$ ). Regression lines are shown for each month. The slope for June is significantly different than for September $(p<0.05)$ 


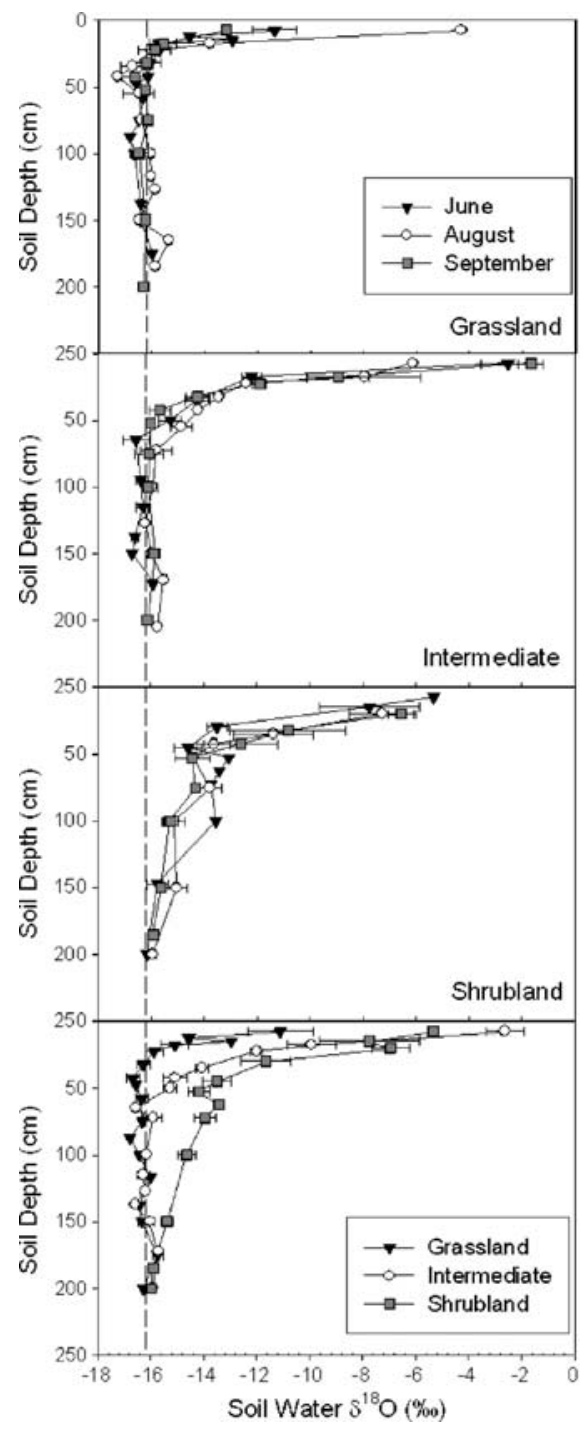

Fig. 3 The oxygen isotopic composition $\left(\delta^{18} \mathrm{O}\right)$ of soil water with depth in the grassland, intermediate, and shrubland sites separated by month in 2006 (top three panels) and average seasonal values for all three sites in 2006 (lower panel). The dotted line shows the isotopic composition of groundwater. Error bars show one standard error (n varies from 1 to 5 replicates in the first 3 panels and from 1 to 10 replicates in the last panel)

sites, values remained less negative than $-2 \mathrm{MPa}$. Water potential did not vary significantly among sites or sampling periods for either shrub species or grasses, with the exception of $A$. torreyi in August, when predawn water potentials were lower in the intermediate site (Fig. 5, $p<0.01$ ).

Leaf level photosynthesis was generally higher in the grass species D. spicata in comparison to the two shrub species (Fig. 6). Photosynthesis of $A$. torreyi was relatively low and constant throughout the season and did not differ between sites or over the season in either 2005 or $2006(p>0.1)$. Photosynthesis of E. nauseosa was also relatively low and constant over the season in 2006; however, photosynthesis of E. nauseosa in 2005 was greater at the intermediate than the shrubland site early in the season, and significantly decreased from June to August in the intermediate site (Fig. 6, $p<0.05$ ). There was a marginally significant trend of greater grass photosynthesis at the grassland site than the shrubland site early in the season in both 2005 and 2006 (Fig. 6, $p<0.1$ ). After the June measurement period, photosynthesis in the grassland site dropped significantly in both 2005 and $2006(p<0.05)$, while at the intermediate and shrubland sites grass photosynthesis remained low and relatively constant throughout the season (Fig. 6).

Total leaf $\mathrm{N}$ was positively correlated with inorganic $\mathrm{N}$ availability across species and sites $\left(\mathrm{r}^{2}=0.34, p<\right.$ 0.05). However, when species were analyzed individually, only $D$. spicata showed a significant relationship $(p<0.05)$. Leaf percent $\mathrm{N}$ was also positively correlated with photosynthesis in D. spicata when data from all sites in both 2005 and 2006 were combined $\left(\mathrm{r}^{2}=0.51, p<0.01\right)$. No relationship between leaf $\mathrm{N}$ and photosynthesis was observed for the other species $(p>$ 0.1 . Photosynthesis was not correlated with stem water isotopes or predawn water potential for any species or site $(p>0.1)$.

\section{Discussion}

$\mathrm{N}$ availability differed among sites, and seasonal declines in soil available inorganic $\mathrm{N}$ were associated with similar declines in plant leaf N. All species showed adequate water availability over the season, and photosynthesis was not correlated with soil water availability or stem water isotopic composition. In sites with greater $\mathrm{N}$ availability, $D$. spicata and E. nauseosa showed seasonal declines in photosynthesis, but photosynthesis was only correlated with $\mathrm{N}$ availability in D. spicata. These results indicate that in sites where groundwater is accessible, $\mathrm{N}$ serves as a strong control on the photosynthetic activity of D. spicata during the summer. 


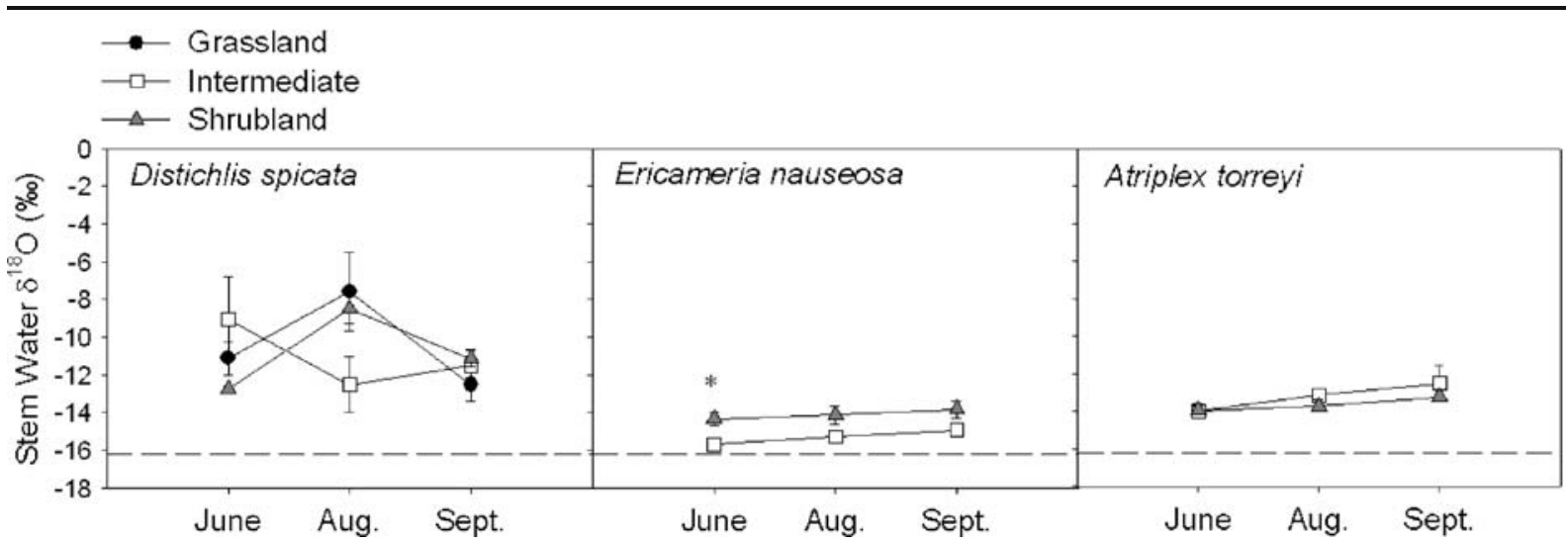

Fig. 4 The oxygen isotopic composition $\left(\delta^{18} \mathrm{O}\right)$ of grass and shrub species in the grassland, intermediate, and shrubland sites in 2006. The dotted line shows the isotopic composition of

Differences in soil resources among sites

The grassland site had more soil organic $\mathrm{N}$ than either the intermediate or shrubland sites (Pataki et al. 2008) and more $\mathrm{KCl}$ extractable soil inorganic $\mathrm{N}$ than the shrubland site (Fig. 1a). A trend of seasonal decreases in soil inorganic $\mathrm{N}$ was apparent under all species at all sites, indicating that soil $\mathrm{N}$ availability decreased over the season. Shallow soil moisture affects nitrogen mineralization rates, and soil texture is an important control on soil water holding ability and evaporation. The grassland and intermediate site soils are composed predominately of silt, while the shrubland soil texture is sandy (Pataki et al. 2008). The larger spaces between sand particles inhibit capillary movement of groundwater, contributing to differences in both soil moisture and soil water isotopic values with depth. Although all sites had groundwater. Error bars show one standard error (n varies from 3 to 5 replicates). Asterisks show significant differences among sites at $\alpha=0.05$

similar water table depths $(1.5-2 \mathrm{~m}), \delta^{18} \mathrm{O}$ of water within the soil profile differed significantly among sites (Fig. 3). For example, soil water in the grassland site was isotopically lighter at shallower depths than the other sites, and soil water at the shrubland site was enriched throughout much of the profile relative to the other sites. Drainage of precipitation through the upper soil profile was likely greatest at the sandy shrubland site. In addition, areas with low vegetative cover, such as the exposed soil in the intershrub spaces at the shrubland site, tend to experience greater soil water evaporation (Noy-Meir 1973) and subsequent enrichment of remaining soil water. Recently, Carbone et al. (2008) reported greater soil moisture at the grassland site compared to the shrubland site at depths up to $35 \mathrm{~cm}$. In that study, soil volumetric water content in these two sites declined over the

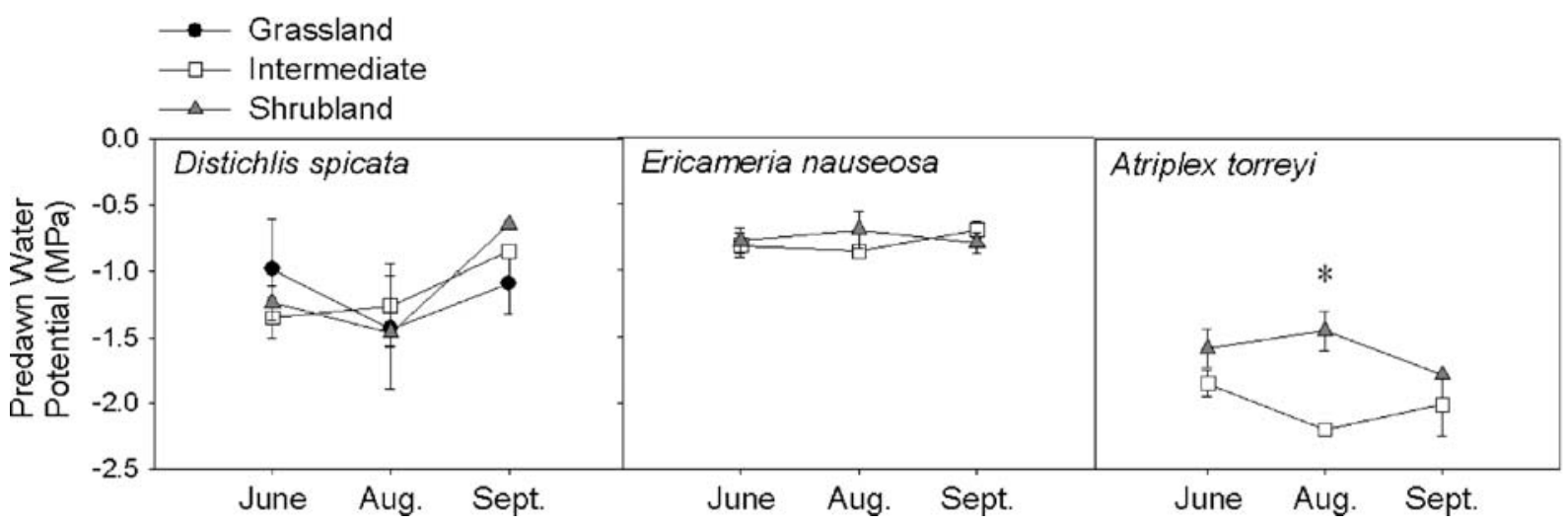

Fig. 5 Predawn water potential (MPa) of grass and shrub species in the grassland, intermediate, and shrubland sites in 2006. Error bars show one standard error (n varies from 3 to 8 replicates). Asterisks show significant differences among sites at $\alpha=0.05$ 


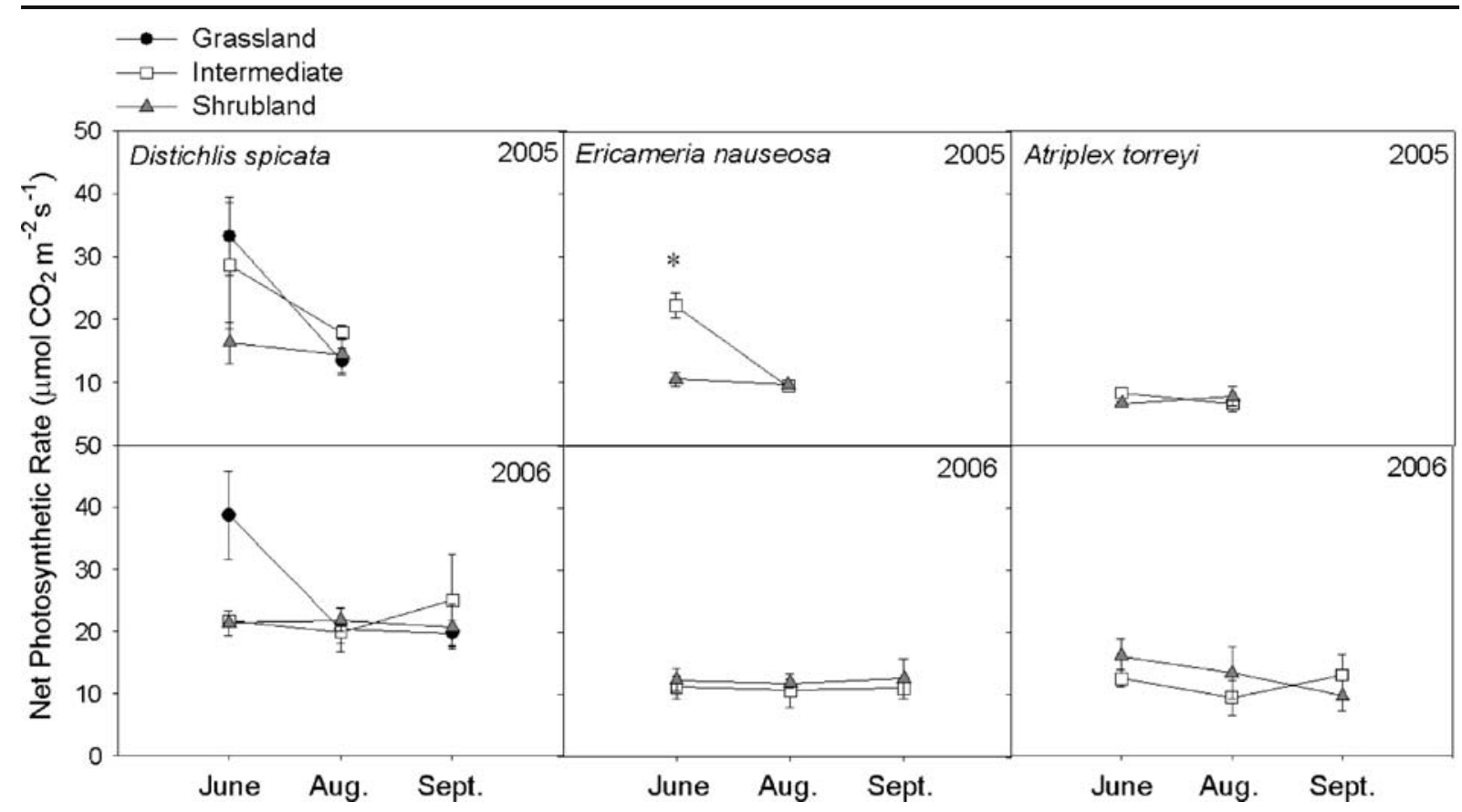

Fig. 6 Leaf level photosynthesis during the 2005 and 2006 growing seasons. Error bars show one standard error (n varies from 3 to 5 replicates). Asterisks show significant differences among sites at $\alpha=0.05$

spring and early summer until mid July, when it remained relatively constant (Carbone et al. 2008).

\section{Plant seasonal $\mathrm{N}$ status}

Because A. torreyi is likely able to access large inorganic N pools in surface soil (Pataki et al. 2008), we didn't expect to see seasonal declines in leaf $\mathrm{N}$ in A. torreyi. However, all species showed declining leaf $\mathrm{N}$ at all sites with the exception of marginal declines in $A$. torreyi in the intermediate site, and constant low seasonal leaf $\mathrm{N}$ in D. spicata in the shrubland site (Fig. 1b). In addition, D. spicata and E. nauseosa in the shrubland site had significantly less leaf $\mathrm{N}$ than plants in the intermediate and grassland sites (Fig. 1b). Soil inorganic $\mathrm{N}$ was lowest at the shrubland site compared to the other two sites, and these two species may not have been able to access the larger $\mathrm{N}$ pools in the surface soil. A caveat is that leaf $\mathrm{N}$ is expressed in this study on a mass basis. While it is not likely that specific leaf area declined during late summer due to an increase in leaf thickness, we cannot rule out this possibility.

Declines in leaf $\mathrm{N}$ are consistent with seasonal declines in soil $\mathrm{KCl}$ extractable inorganic N (Fig. 1a). Seasonal reductions in leaf $\mathrm{N}$ may have been due to plant $\mathrm{N}$ resorption, which is common in these species (Aerts 1996; Carrera et al. 2003; Drenovsky and Richards 2004, 2006), or increases in N use efficiency. However, we showed previously that leaf $\mathrm{N}$ and leaf nitrogen isotopes were strongly correlated at these sites (Pataki et al. 2008). In this study, we found that the slope of this relationship increases throughout the growing season, due predominately to the increase of leaf $\mathrm{C}: \mathrm{N}$ in $E$. nauseosa late in the season and the isotopic enrichment of leaf $\mathrm{N}$ in both the shrub $E$. nauseosa and the grass D. spicata (Fig. 2). A likely explanation is that gaseous $\mathrm{N}$ loss via ammonia volatilization, nitrification and denitrification causes progressive $\delta^{15} \mathrm{~N}$-enrichment of remaining soil inorganic $\mathrm{N}$, and subsequently plant $\mathrm{N}$ during the growing season (Billings et al. 2002, 2004; Robinson 2001). The increase in leaf $\mathrm{C}: \mathrm{N}$ in E. nauseosa late in the season indicates that continued $\mathrm{C}$ fixation without additional inputs of $\mathrm{N}$ caused a shift in leaf stoichiometry, consistent with constant rates of photosynthesis despite declining $\mathrm{N}$ availability.

\section{Plant seasonal water status}

All species likely had adequate access to groundwater at all sites during the study period. Grasses in this 
region are expected to have a maximum rooting depth of $2.5 \mathrm{~m}$, and shrubs are thought to have rooting depths that extend beyond that of neighboring grasses (Elmore et al. 2006). Depth to groundwater remained within $2 \mathrm{~m}$ throughout the summer at each site. The isotopic composition of root water in D. spicata indicated that grasses utilized isotopically enriched shallow soil water to a larger extent than the shrub species (Fig. 4). This is consistent with assumptions about the rooting depths of grasses vs. shrubs and similar to previous measurements (Pataki et al. 2008). Plant water source remained relatively constant over the season for all species, with the exception of stem water enrichment in D. spicata in the shrubland site after a rain event in August, and seasonal enrichment of stem water in E. nauseosa in the intermediate site (Fig. 4). Enrichment in D. spicata in August is likely due to utilization of more shallow soil water from precipitation. Desert shrub species are generally less responsive to summer rain events than herbaceous species; in particular, phreatophytic species tend to respond very little, if at all, to summer monsoons (Donovan and Ehleringer 1994; Ehleringer et al. 1991). E. nauseosa has previously been found to be unresponsive to summer precipitation (Donovan and Ehleringer 1994; Ehleringer et al. 1991; Flanagan et al. 1992; Lin et al. 1996; Pataki et al. 2008). The seasonal stem water isotopes of $E$. nauseosa and $A$. torreyi indicate deep water use throughout the season, and do not show any large seasonal changes in soil water source (Fig. 4).

None of the species showed evidence of increased water stress over the season (Fig. 5). Generally, $A$. torreyi exhibited the most negative predawn water potentials of the three species. Water potential of $A$. torreyi in August was more negative in the intermediate site than in the shrubland site (Fig. 5). However, predawn water potential measurements for the species in this study may not be an accurate measure of soil water availability. In halophytic species such as $D$. spicata and A. torreyi, osmotic potentials may play an important role in the overall plant water potential (Donovan et al. 2001). The large differences between sites in A. torreyi in August may be due to osmotic effects, as the soil in the intermediate site is more saline than at the shrubland site (Pataki et al. 2008). In addition, E. nauseosa has often been shown to exhibit disequilibrium between predawn plant and soil water potential due to several mechanisms including night- time transpiration, solute loading, and hydraulic lift (Donovan et al. 1999, 2001, 2003). Nevertheless, these measurements are useful indicators that there were not large seasonal changes in water availability during the study. The lack of correlation between water sources and photosynthetic rates supports this conclusion.

\section{Photosynthesis}

Because both $D$. spicata and E. nauseosa have previously been shown to utilize deeper and smaller pools of soil N, we expected seasonal declines in leaf photosynthesis in both of these species. Photosynthesis of D. spicata decreased over the season in the grassland site in both 2005 and 2006, but did not change in either the intermediate or shrubland site (Fig. 6). It is unclear why there was a seasonal change in photosynthesis only in the grassland site, considering that soil inorganic $\mathrm{N}$ and leaf $\mathrm{N}$ were similar in both the grassland and intermediate site. However, it is possible that there was inadequate shallow soil water availability in the intermediate site, as $D$. spicata has previously been found to be co-limited by shallow soil water and N (James and Richards 2005). Leaf N was correlated with photosynthesis in D. spicata when both years were combined, and leaf $\mathrm{N}$ was correlated with total soil organic $\mathrm{N}$ in 2006, suggesting that nutrient availability may be a strong control on D. spicata photosynthesis during the summer period. Previous studies have shown that establishment of perennial grasses is favored at higher concentrations of inorganic $\mathrm{N}$ than necessary for neighboring shrubs (Bisigato and Bertiller 1999; Carrera et al. 2003; Van Auken 2000).

Photosynthesis of $E$. nauseosa declined in the intermediate site in 2005 , but remained constant in the intermediate site in 2006 and in the shrubland site in both 2005 and 2006 (Fig. 6). There was no correlation between photosynthesis and $\mathrm{N}$ availability, suggesting that leaf $\mathrm{N}$ concentrations were greater than the requirements for photosynthesis, perhaps because other nutrients were limiting. In previous studies in Owens Valley, E. nauseousa has been shown to be phosphorus limited when water is available (Drenovsky and Richards 2004, 2006).

Photosynthesis in A. torreyi was predicted to remain constant throughout the season, due to adequate access to soil inorganic $\mathrm{N}$ pools. Indeed, 
seasonal photosynthetic rates in this species did not change in either site in 2005 or 2006 (Fig. 6). As with E. nauseosa, there was no correlation between photosynthesis and $\mathrm{N}$ availability, possibly indicating that carbon uptake was not limited by $\mathrm{N}$ availability. We also observed relatively high leaf $\mathrm{N}$ concentrations associated with the most isotopically enriched leaf $\mathrm{N}$ in $A$. torreyi. This species may be well adapted for $\mathrm{N}$ uptake in the shallow, isotopically enriched surface soils (Pataki et al. 2008). Recent demographic studies in Owens Valley indicate that the relative abundance of $A$. torreyi may be increasing (Manning 2006). The results from this study suggest that an expansion of $A$. torreyi cover is consistent with a greater ability to extract soil surface $\mathrm{N}$ at sites with relatively large gaseous $\mathrm{N}$ losses, in addition to greater rooting depth and salinity tolerance in this species.

\section{Conclusions}

In this study, soil inorganic $\mathrm{N}$ availability declined during the growing season. Measurements of $\mathrm{N}$ availability and leaf $\mathrm{N}$ were correlated with photosynthesis in the grass D. spicata, but not in the shrub species A. torreyi or E. nauseosa. Seasonal declines in photosynthesis were observed in D. spicata and $E$. nauseosa, but only in the sites with greater soil inorganic $\mathrm{N}$. Leaf $\mathrm{N}$ in all species declined throughout the season in conjunction with decreasing soil inorganic N. This relationship was significant for $D$. spicata across all three sites. The distribution of $D$. spicata is consistent with this trend, as the grassdominated site was associated with the greatest soil $\mathrm{N}$ availability. Further studies are needed to better understand the controls and limitations of photosynthesis in $A$. torreyi, which was fairly constant both in space and in time, despite large differences in $\mathrm{N}$ availability across sites. However, our results suggest that in this shallow groundwater ecosystem, N availability may be an important control on photosynthesis of D. spicata.

Acknowledgements We thank Jonathan Cheng, Heather Rhee, and Trung Nguyen for their assistance in the field, Greg Cane, Alexis Reed, Lisa Tiemann, Dachun Zhang, and Guihong Zhang for their assistance in the laboratory, and the Los Angeles Department of Water and Power for access to their property. This research was funded by the UC Center for Water Resources grant WR-986 and the University of Kansas General Research Fund allocation 2301447.

Open Access This article is distributed under the terms of the Creative Commons Attribution Noncommercial License which permits any noncommercial use, distribution, and reproduction in any medium, provided the original author(s) and source are credited.

\section{References}

Aerts R (1996) Nutrient resorption from senescing leaves of perennials: are there general patterns? J Ecol 84:597-608

Bilbrough CJ, Caldwell MM (1997) Exploitation of springtime ephemeral $\mathrm{N}$ pulses by six Great Basin plant species. Ecology 78:231-243

Billings SA, Schaeffer SM, Zitzer S, Charlet T, Smith SD, Evans RD (2002) Alterations of nitrogen dynamics under elevated carbon dioxide in an intact Mojave Desert ecosystem: evidence from nitrogen-15 natural abundance. Oecologia 131:463-467

Billings SA, Schaeffer SM, Evans RD (2004) Soil microbial activity and $\mathrm{N}$ availability with elevated $\mathrm{CO}_{2}$ in Mojave Desert soils. Glob Biol Cycles 18:GB1011

Bisigato AJ, Bertiller MB (1999) Seedling emergence and survival in contrasting soil microsites in Patagonian Monte shrubland. J Veg Sci 10:335-342

Carbone MS, Winston GC, Trumbore SE (2008) Soil respiration in perennial grass and shrub ecosystems: linking plant and microbial sources with environmental controls on seasonal and diel timescales. J Geophys Res 113:G02022

Carrera AL, Bertiller MB, Sain CL, Mazzarino MJ (2003) Relationship between plant nitrogen conservation strategies and the dynamics of soil nitrogen in the arid Patagonian Monte, Argentina. Plant Soil 255:595-604

Cui M, Caldwell MM (1997) A large ephemeral release of nitrogen upon wetting of dry soil and corresponding root responses in the field. Plant Soil 191:291-299

Dahlgren RA, Richards JH, Yu Z (1997) Soil and groundwater chemistry and vegetation distribution in a desert playa, Owens Lake, California. Arid Soil Res Rehabil 11:221244

Donovan LA, Ehleringer JR (1994) Water stress and use of summer precipitation in a Great Basin shrub community. Funct Ecol 8:289-297

Donovan LA, Grisé DJ, West JB, Pappert RA, Alder NN, Richards JH (1999) Predawn disequilibrium between plant and soil water potentials in two cold-desert shrubs. Oecologia 120:209-217

Donovan LA, Linton MJ, Richards JH (2001) Predawn plant water potential does not necessarily equilibrate with soil water potential under well-watered conditions. Oecologia 129:328-335

Donovan LA, Richards JH, Linton MJ (2003) Magnitude and mechanisms of disequilibrium between predawn plant and soil water potentials. Ecology 84:463-470 
Drenovsky RE, Richards JH (2004) Critical N:P values: predicting nutrient deficiencies in desert shrublands. Plant Soil 259:59-69

Drenovsky RE, Richards JH (2006) Low leaf N and P resorption contributes to nutrient limitation in two desert shrubs. Plant Ecol 183:305-314

Ehleringer JR, Phillips SL, Schuster WSF, Sandquist DR (1991) Differential utilization of summer rains by desert plants. Oecologia 88:430-434

Elmore AJ, Mustard JF, Manning SJ (2003) Regional patterns of plant community response to changes in water: Owens Valley, California. Ecol Appl 13:443-460

Elmore AJ, Manning SJ, Mustard JF, Craine JM (2006) Decline in alkali meadow vegetation cover in California: the effects of groundwater extraction and drought. J Appl Ecol 43:770-779

Flanagan LB, Ehleringer JR, Marshall JD (1992) Differential uptake of summer precipitation among co-occuring trees and shrubs in a pinyon-juniper woodland. Plant Cell Environ 15:831-836

Gebauer RLE, Ehleringer JR (2000) Water and nitrogen uptake patterns following moisture pulses in a cold desert community. Ecology 81:1415-1424

Gehre M, Geilmann H, Richter J, Werner RA, Brand WA (2004) Continuous flow ${ }^{2} \mathrm{H} /{ }^{1} \mathrm{H}$ and ${ }^{18} \mathrm{O} /{ }^{16} \mathrm{O}$ analysis of water samples with dual inlet precision. Rapid Commun Mass Spectrom 18:2650-2660

Griepentrog TE, Groeneveld DP (1981) The Owens Valley management report. Prepared for the County of Inyo, California

Groeneveld DP, Or D (1994) Water-table induced shrubherbaceous ecotone-hydrologic management implications. Water Resour Bull 30:911-920

Groeneveld DP, Warren DC, Hubbard PJ (1994) Responses of five dominant Owens Valley scrub phreatophytes to controlled water table drawdown. Prepared for the County of Inyo and City of Los Angeles Technical Group

Hadley NF, Szarek SR (1981) Productivity of Desert Ecosystems. Bioscience 31:747-753

James JJ, Richards JH (2005) Plant N capture from pulses: effects of pulse size, growth rate, and other soil resources. Oecologia 154:113-122

James JJ, Richards JH (2006) Plant nitrogen capture in pulsedriven systems: interactions between root responses and soil processes. J Ecol 94:765-777

James JJ, Richards JH (2007) Influence of temporal heterogeneity in nitrogen supply on competitive interactions in a desert shrub community. Oecologia 15:721-727

James JJ, Tiller RL, Richards JH (2005) Multiple resources limit plant growth and function in a saline-alkaline desert community. J Ecol 93:113-126

James JJ, Aanderud ZT, Richards JH (2006) Seasonal timing of $\mathrm{N}$ pulses influences $\mathrm{N}$ capture in a saltbush scrub community. J Arid Environ 67:688-700
Leffler AJ, Ivans CY, Ryel RJ, Caldwell MM (2004) Gas exchange and growth responses of the desert shrubs Artemisia tridentata and Chrysothamnus nauseosus to shallow- vs. deep-soil water in a glasshouse experiment. Environ Exp Bot 51:9-19

Lin G, Phillips SL, Ehleringer JR (1996) Monsoonal precipitation responses of shrubs in a cold desert community on the Colorado Plateau. Oecologia 106:8-17

Manning SJ (2006) Status of re-inventoried vegetation parcels according to the Drought Recovery Policy, 2005. Inyo Technical Report, Inyo County Water Department, Bishop, California, USA

McLendon T, Redente EF (1992) Effects of nitrogen limitation on species replacement dynamics during early secondary succession on a semiarid sagebrush site. Oecologia 91:312-317

Naumburg E, Mata-Gonzalez R, Hunter RG, McLendon T, Martin DW (2005) Phreatophytic vegetation and groundwater fluctuations: a review of current research and application of ecosystem response modeling with an emphasis on Great Basin vegetation. Environ Manag 35:726-740

Noy-Meir I (1973) Desert ecosystems: environment and producers. Annu Rev Ecol Syst 4:25-51

Pataki DE, Bush SE, Gardner P, Solomon DK, Ehleringer JR (2005) Ecohydrology in a Colorado River riparian forest: implications for the decline of Populus fremontii. Ecol Appl 15:1009-1018

Pataki DE, Billings SA, Naumburg E, Goedhart CM (2008) Water sources and nitrogen relations of grasses and shrubs in phreatophytic communities of the Great Basin Desert. J Arid Environ 72:1581-1593

Robinson D (2001) $\delta 15 \mathrm{~N}$ as an integrator of the nitrogen cycle. Trends Ecol Evol 16:153-162

Snyder KA, Donovan LA, James JJ, Tiller RL, Richards JH (2004) Extensive summer water pulses do not necessarily lead to canopy growth of Great Basin and northern Mojave Desert shrubs. Oecologia 141:325-334

Sorenson SK, Dileanis PD, Branson FA (1991) Soil water and vegetation responses to precipitation and changes in groundwater in Owens Valley, California. Denver, Water Supply Paper 2370-C, USGS

Steinwand AL, Harrington RF, Or D (2006) Water balance for Great Basin phreatophytes derived from eddy covariance, soil water, and water table measurements. J Hydrol 329:595-605

Toft CA (1995) A 10-year demographic study of rabbitbrush (Chysothamnus nauseosus): growth, survival and water limitation. Oecologia 101:1-12

Van Auken OW (2000) Shrub invasions of North American semiarid grasslands. Annu Rev Ecol Syst 31:197-215

West AG, Patrickson SJ, Ehleringer JR (2006) Water extraction times for plant and soil materials used in stable isotope analysis. Rapid Commun Mass Spectrom 20:1317-1321 